\title{
Entamoeba histolytica Neglected Tropical Diseases (NTDs) Agents that Infect Humans and Some Other Mammals: A Review
}

\author{
Junaidi Junaidi ${ }^{1 *}$, Umi Cahyaningsih ${ }^{1}$, Trioso Purnawarman ${ }^{1}$, Hadri Latif ${ }^{1}$, Etih Sudarnika ${ }^{1}$, Zinatul Hayati $^{2}$, and \\ Muslina Muslina ${ }^{3}$ \\ ${ }^{1}$ Department of Animal Diseases and Veterinary Health, Faculty of Veterinary Medicine, IPB University, Bogor, Indonesia \\ ${ }^{2}$ Department of Microbiology, Faculty of Medicine, Syiah Kuala University, Banda Aceh, Indonesia \\ ${ }^{3}$ Technical Unit for Implementation of Artificial Insemination and Incubator Livestock of Aceh Province, Jantho, Indonesia
}

\begin{abstract}
Amoebiasis caused by Entamoeba histolytica is an important issue in world public health because it is associated with high morbidity and mortality. Entamoeba histolytica is the only species of its genus that commonly causes mild irritation, injury, to inflammation of the walls of the colon and cecum. In some cases, parasites also invade other organs, especially the liver, lungs, kidneys, and brain. Methods: Our article search uses the help of four search engines namely Google Scholar, PubMed, Science Direct, and Springer. Results: Entamoeba histolytica is not easily transmitted from animals to humans, due to the fact that this parasite rarely encysts in the intestinal lumen of animals which is an important factor in the transmission of this parasite. And conversely, subclinical amebiasis in humans acts as the dominant host for transmission of this parasite either from human to human or from human to animal.
\end{abstract}

Keywords: Entamoeba histolytica, amoebiasis, zoonotic potential.

\section{Introduction}

Entamoeba histolytica is a pathogenic intestinal protozoan that is transmitted through water and food [1] [8]. This parasite is the only species of its genus that can cause mild irritation, injury, to inflammation of the walls of the colon and cecum [2,5]. In some cases (4-10\%), parasites can invade other organs, especially the liver, lungs, kidneys, and brain $[1,8,48]$. E. histolytica infection causes amebiasis, and based on the location of the infection, amebiasis is divided into two types namely intestinal amebiasis and extraintestinal amebiasis $[4,16]$. Extraintestinal amebiasis is an advanced stage of infection and if it does not get proper therapy it can be fatal $[5,6,7]$.

Amebiasis is now rarely reported, even though the disease is still ranked third most deaths originating from parasitic agents after malaria and schistosomiasis $[9,17]$. Case reports do not compare to the proportion of population deaths correlated with subclinical amebiasis patients who are undetected and without treatment. Patients with subclinical amebiasis for a long time are likely to become extraintestinal amebiation which often results in fatality [3]. In addition, their sufferers also act as carriers of infective cyst transmission to other hosts. These phenomena of amebiasis are often overlooked and difficult to eliminate in a community or state $[7,18,37]$.

Besides humans, E. histolytica also infects Nonhuman primates (NHPs), cats, and dogs $[38,39,41,42]$, and scientific studies have been widely reported.
However, there are no reports of cases of amebiasis transmitted from humans or vice versa, causing a lack of

scientific studies that can answer the phenomenon of the transmission of this parasite across species. This review literature, we try to provide a scientific view of $E$. histolytica infection in humans and some mammals.

\section{Materials and Methods}

Our article search strategy uses the help of four search engines namely Google Scholar, PubMed, Science Direct, and Springer. The eligibility criteria are carried out by collecting all article titles and abstracts containing $E$. histolytica words or sentences, infections in humans or residents or groups of people, infections in Non-human primates (NHPs), infections in cats, and infections in dogs.

\section{Results and Discussion}

\subsection{Results}

We have scanned 317 titles and abstracts of scientific articles that contain the main words or sentences in the search engine, we found 119 article titles that match the aspects of our study. After reading one by one the abstract from the title, we picked 51 articles that were worthy of review. 


\subsection{Discussion}

\subsubsection{Entamoeba histolytica is the causative agent for amebiasis}

Entamoeba histolytica is an intestinal parasite that causes amebiasis originating from the Sarcomastigophora phylum, the Lobosea class, the Endamoebidae family, the Amoebida order and the genus Entamoeba [43]. Symptoms of the disease are identical agents that cause amebiasis has long been mentioned by Hippocrates (460$377 \mathrm{BC})$ as a disease of fever and deadly dysentery $[19,20]$. Only around 1875, a doctor from Russia, Dr. Losch managed to isolate the invasive organisms originating from the feces of chronic dysentery patients, then through long research in 1903 Schaudinn named the organism as E. histolytica. In the last two decades, the taxonomy of E. histolytica has changed significantly because there are two more species namely E. dispar, and E. moshkovskii which are very identical to them but are very different from the structure of DNA and biochemical molecules [10]. And of the three, only E. histolytica is pathogenic while the others are only commensal organisms [21].

Entamoeba histolytica and other intestinal amoebas can be detected microscopically, antigenic and antibody reactions, culture, and Polymerase chain reaction (PCR) [22]. Of these methods, microscopic methods are the Gold Standard for diagnosing diseases caused by this parasite. Besides being inexpensive, microscopic methods can also observe cell characteristics which are then used as species markers [23]. By distinguishing three species of identical morphological Entamoeba based on differences in genetic and biochemical structures, causing microscopic methods can not be used as the primary choice to distinguish these identical morphological species $[22,24]$. However, since the widespread introduction of isoenzyme molecular identification methods, the method for identifying identical Entamoeba has not become an obstacle anymore $[19,26]$.

The life cycle of $E$. histolytica includes trophozoite stages, precystes, cysts, metacysts, and metacystic tropoozoites (Figure 1) [14,25]. Stage E. histolytica transition is strongly influenced by factors of food availability and environmental stress. Favorable environmental conditions, this parasite is in the excitation phase, namely the release of tropozoites from cysts that have the potential to invade tissue. Whereas, in a less conducive environmental condition, the parasite is in an enistation phase, namely the formation of cysts from tropozoites which have the potential to infect new hosts [27].

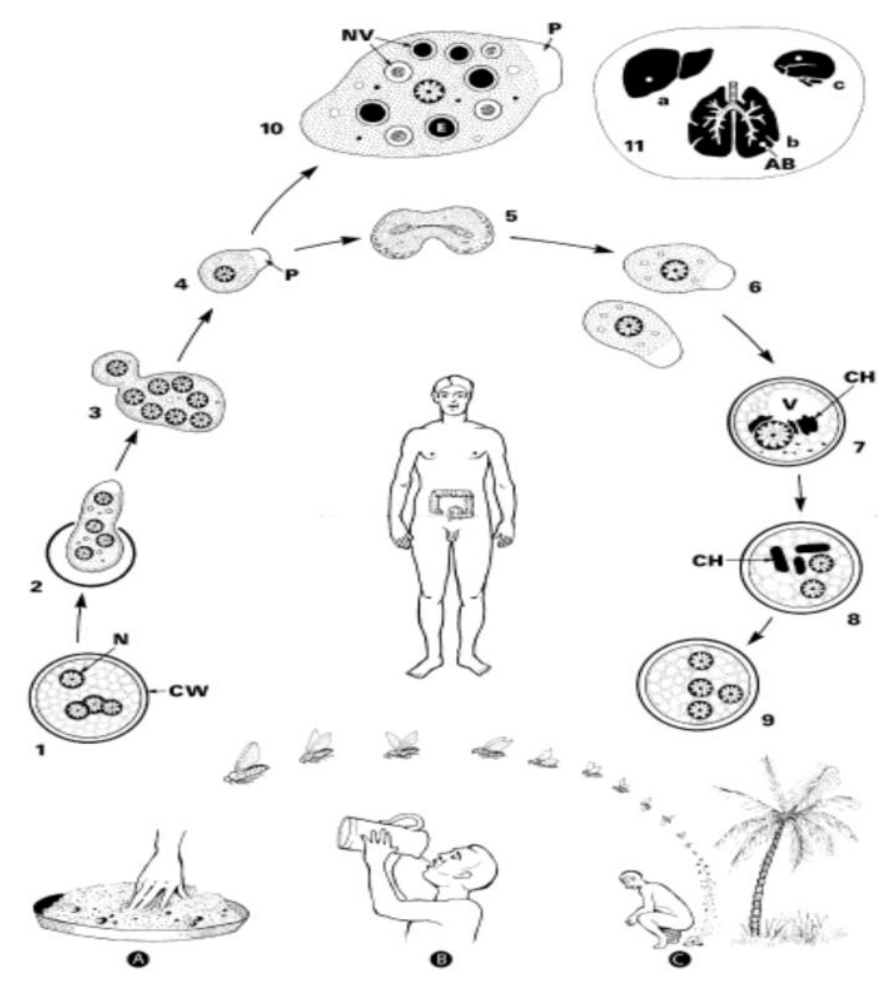

Figure 1. Life cycle of E. histolytica. 1) Cyst with 4 nuclei (metacyst) from contaminated food or drinking water (A-C). 2-4) Once in the small intestine, the cytoplasm and nucleus are divided into 8 small amoebulae (metacystic to trophozoites). 5,6) adult trophozoites (minuta form) reproduce by binary fission 7) Non-nucleated cysts (precursors) containing large chromatoid objects and glycogen vacuoles. 8) Cyst with 2 nuclei and body chromatoid. 9) Metacyst is excreted with the patient's stool and transmits another host. 10 11) Some forms of minuta can grow into histolytic (magna) forms, penetrate the intestinal wall and through the bloodstream, to other organs such as the liver, lungs, and brain (11 ac), parasites cause abscesses (amoebomae). Live amoebas are only found at the edge of this amoeboma. $\mathrm{AB}$, abscess; $\mathrm{CH}$, body chromatoid; $\mathrm{CW}$, cyst wall; E, erythrocytes; $\mathrm{P}$, singular, pale pseudopodium; N, Nucleolus (karyosome); NV, food vacuoles; V, young glycogen vacuoles of young cysts [13]. 


\subsubsection{Pathogenicity and clinical symptoms}

Estimated that 10-20 E. histolytica cyst cells that are ingested can cause disease especially in susceptible hosts. One infective cyst cell that is swallowed, will divide into eight young trophozoites and do not have the ability to invade tissue [11]. Under ideal environmental conditions, trophozoites quickly reach maturity. Mature trophozoites adhere easily and cause damage to tissue structures mediated by galactose or N-acetyl-D-galactosamine (GalNAc) and N-acetyl-D-glucosamine (GlcNAc) polymers [3]. In addition, several other specific enzymes such as proteinase, phospholipase, and hemolysin also act as synergistic factors, cell adhesion and cell damage $[12,28]$.

The incubation period for E. histolytica can be several days to several months. Symptomatic sufferers often experience diarrhea and abdominal pain. In advanced infections, patients can experience diarrhea with feces mixed with blood, mucus, and pus [29] [30]. Biologically, E. histolytica has the ability to be able to invade and migrate. The form of E. histolytica cyst can never be formed in tissue, and tissue invasion is a deadend form in its life cycle. This also shows that E. histolytica is an opportunistic pathogen and invasion occurred accidentally $[14,15,36]$.

Entamoeba histolytica is one of the water-borne zoonotic agents $[14,40]$. Besides humans, some mammals that can be infected by E. histolytica are Non-human primates (NHPs), cats, and dogs [1,38,39,41] (Table 1). Other animals such as mice and pigs can also be infected with this parasite, but only act as a transit host [42]. E. histolytica infections in humans originating from animals almost never occur [35]. This may be related to the characteristics of parasites which very rarely encysts in the intestinal lumen of animals [42].

Table. 1 Prevalence of E. histolytica infections in humans and some mammals

\begin{tabular}{|c|c|c|c|c|c|}
\hline \multirow{3}{*}{ Research Title } & \multicolumn{4}{|c|}{ Examination Methods $(\%)$} & \multirow[t]{3}{*}{ References } \\
\hline & Number and & Micros & ELISA & PCR & \\
\hline & type of sample & copic & & & \\
\hline $\begin{array}{l}\text { Entamoeba infections in different populations of dogs in an } \\
\text { endemic area of Lahore, Pakistan }\end{array}$ & $\begin{array}{l}600 \text { dog faeces } \\
\text { samples }\end{array}$ & 55,7 & 11 & & $\begin{array}{l}\text { Alam et al. } \\
2015\end{array}$ \\
\hline $\begin{array}{l}\text { Factors Associated with High Prevalence of Intestinal } \\
\text { Protozoan Infections among Patients in Sana'a City, } \\
\text { Yemen }\end{array}$ & $\begin{array}{l}503 \text { man clinical } \\
\text { stool samples }\end{array}$ & 17,1 & & & $\begin{array}{l}\text { Alyousefi et } \\
\text { al. } 2011\end{array}$ \\
\hline $\begin{array}{l}\text { Prevalence of Entamoeba histolytica among Primary } \\
\text { School children in Ukwa West Local Government Area, } \\
\text { Abia State, South East, Nigeria. }\end{array}$ & $\begin{array}{l}300 \text { stool samples } \\
\text { from children } \\
\text { aged } 0-14\end{array}$ & 16 & & & $\begin{array}{l}\text { Amaechi et al. } \\
2014\end{array}$ \\
\hline $\begin{array}{l}\text { Different Clinical Outcomes of Entamoeba histolytica in } \\
\text { Malaysia: Does Genetic Diversity Exist? }\end{array}$ & $\begin{array}{l}500 \text { stool samples } \\
\text { population }\end{array}$ & 18,60 & & 5,6 & $\begin{array}{l}\text { Anuar et al. } \\
2013\end{array}$ \\
\hline $\begin{array}{l}\text { Entamoeba dispar, Entamoeba moshkovskii, and } \\
\text { Entamoeba hartmanni in the context of water scarcity in } \\
\text { northeastern Brazil }\end{array}$ & $\begin{array}{l}213 \text { stool samples } \\
\text { population }\end{array}$ & 10,30 & & & $\begin{array}{l}\text { Calegar et al. } \\
2016\end{array}$ \\
\hline $\begin{array}{l}\text { Prevalence of Entamoeba histolytica, Giardia lamblia, and } \\
\text { Cryptosporidium spp. in Libya: 2000-2015 }\end{array}$ & - & 19,90 & & & $\begin{array}{l}\text { Ghenghesh et } \\
\text { al. } 2016\end{array}$ \\
\hline $\begin{array}{l}\text { Molecular identification of Entamoeba spp. in captive } \\
\text { nonhuman primates. }\end{array}$ & $\begin{array}{l}520 \text { sampel feses } \\
\text { population }\end{array}$ & & & 36,0 & $\begin{array}{l}\text { Levecke et al. } \\
2018\end{array}$ \\
\hline $\begin{array}{l}\text { Prevalence of Entamoeba species in captive primates in } \\
\text { zoological gardens in the UK }\end{array}$ & $\begin{array}{l}37 \text { in captive } \\
\text { primates }\end{array}$ & & & 16,2 & $\begin{array}{l}\text { Regan et al. } \\
2014\end{array}$ \\
\hline $\begin{array}{l}\text { Prevalence of intestinal parasites among expatriate workers } \\
\text { in Al-Khobar, Saudi Arabia }\end{array}$ & $\begin{array}{l}1,019 \text { medical } \\
\text { files from } \\
\text { expatriate workers }\end{array}$ & 9,2 & & & $\begin{array}{l}\text { Abahussain } \\
\text { and } \\
\text { Abahussai. } \\
2005\end{array}$ \\
\hline $\begin{array}{l}\text { Intestinal parasitic infections in Campalagian district, south } \\
\text { Sulawesi, Indonesia }\end{array}$ & $\begin{array}{l}380 \text { samples } \\
\text { population stool }\end{array}$ & 10,9 & & & $\begin{array}{l}\text { Mangali et al. } \\
1993\end{array}$ \\
\hline Status of gastrointestinal parasites in Red Panda of Nepal & $\begin{array}{l}272 \text { samples Red } \\
\text { Panda stool }\end{array}$ & 7,41 & & & $\begin{array}{l}\text { Bista et al. } \\
2017\end{array}$ \\
\hline $\begin{array}{l}\text { A Survey of Intestinal Parasites of Domestic Dogs in } \\
\text { Central Queensland }\end{array}$ & $\begin{array}{l}300 \text { samples dog's } \\
\text { stool }\end{array}$ & $<1$ & & & $\begin{array}{l}\text { Gillespie et al. } \\
2017\end{array}$ \\
\hline $\begin{array}{l}\text { Intestinal parasitic infestations and anemia among urban } \\
\text { female school children in Kancheepuram district, Tamil } \\
\text { Nadu }\end{array}$ & $\begin{array}{l}360 \text { samples of } \\
\text { adolescent student } \\
\text { stool }\end{array}$ & 23.2 & & & $\begin{array}{l}\text { Gopalakrishna } \\
\mathrm{n} \text { et al. } 2018\end{array}$ \\
\hline
\end{tabular}


Three important pathways that contribute to the spread and spread of E. histolytica are 1) person to person transmission; 2) water and foodborne transmission and 3) borne transmission vector $[32,33,45]$. Other factors that can also increase the risk of disease transmission are malnutrition, poverty, low education, population density, inadequate water supply, and poor sanitation $[44,15]$. Fruits and vegetables that are eaten raw are not peeled and not washed properly as a medium for entry of various parasites into the digestive system [31,47]. Parasitic cysts do not die by water chlorination and detergents. However, washing with detergent and running water can dissolve attached parasites and carry water. Cysts can also be damaged with 5\% acetic acid or low heating for 15 minutes $[34,45,36]$.

\section{Conclusion}

Entamoeba histolytica is a parasite that causes amebiasis, a disease caused by this parasite as the third leading cause of death after malaria and schistosomiasis. Besides humans, E. histolytica also infects non-human primates, dogs, cats, and red pandas with very varied proportions. Although this parasite can infect several types of mammals. However, so far we have not found reports of human amebiasis from animals. We argue that $\mathrm{E}$. histolytica is not easily transmitted from animals to humans, which is due to the fact that this parasite rarely encysts in the intestinal lumen of animals which is an important factor in the transmission of this parasite. And conversely, subclinical amebiasis in humans acts as the dominant host for transmission of this parasite either from human to human or from human to animal.

\section{References}

1. Schuster FL, Visvesvara GS: Amebae and ciliated protozoa as causal agents of waterborne zoonotic disease. Vet Parasitol. 2014; 6(1-2):91-120.

2. Haque R, Huston CD, Hughes M, et al. : Amebiasis. $N$. Engl. J. Med. 2003; 348(16):1565-1573.

3. Steve Cornick S, Chadee K.: Entamoeba histolytica: Host parasite interactions at the colonic epithelium. Tissue Barriers. 2017; 5(1):1-4.

4. Ximénez C, Cerritos R, Rojas L, et al. : Human Amebiasis: Breaking the Paradigm?. Int J Environ Res Public Health. 2010; 7(3):1105-1120.

5. Espinosa-Cantellano $\mathrm{M}$, Martiânez-Palomo A: Pathogenesis of intestinal amebiasis: from molecules to disease. Clinical Microbiology Reviews. 2000; 13(2):318331.

6. Nowak P, Mastalska K, Loster J: Entamoeba histolytica pathogenic protozoan of the large intestine in humans. J Clin Microbiol Biochem Technol. 2015; 1(1):010-017.

7. WHO World Health Organization: Weekly epidemiological record. [Internet]. Geneva (FR). 72 (14). P 97-100; [download 2018 Mar 27]. Available on: http://www.meridianbioscience.eu/media/pdf/WHO\%201 997\%20wer72\%2014\%2097-99.pdf.

8. Karim A, Alavi MD: Amebiasis. Clin Colon Rectal Surg. 2007; 20(1):33-37.
9. Skappak C, Akierman S, Belga S, et al. : Novak K, Chadee K, Urbanski SJ, Church D, Beck PL. Can J Gastroenterol Hepatol. 2014; 28(7):355-359.

10. Ximénez C, Morán P, Rojas L, et al. : Reassessment of the epidemiology of amebiasis: state of the art. Infect Genet Evol. 2009; 9(6):1023-1032.

11. Nozaki T, Bhattacharya A: Amebiasis Biology and Pathogenesis of Entamoeba. Nozaki T, Bhattacharya A. editor. Springer. (JP) Tokyo . 2015.

12. Houpt E, Hung C: Entamoeba histolytica (amebiasis). Magil AJ, Ryan ET, Hil D, Solomon T. Di dalam: Hunter's Tropical Medichine and Emerging Infectious Diseases. Editor, Saunders. London (NZ): Elserver. 2013.

13. Mehlhorn H: Encyclopedia of Parasitology. Edisi Ketiga. Düsseldorf (DE): Springer. 2008.

14. Marshall MM, Naumovitz D, Ortega Y, et al. : Waterborne protozoan pathogens. Clin Microb Rev. 1997; 10(1):67-85

15. Zaki M, Andrew N, Insall RH: Entamoeba histolytica cell movement: a central role for self-generated chemokines and chemorepellent. PNAS. 2016; 103(49): 18751-18756.

16. Ali IK: Intestinal amebae. Clin Lab Med. 2015; 35:393422.

17. Lucas R, Upcroft JA: Clinical significance of the redefinition of the agent of amoebiasis. Rev. Latinoam Microbiol. 2001; 43(4):183-187.

18. Salles JM, Salles MJ, Moraes LA, et al. : Invasive amebiasis: an update on diagnosis and management. Expert Rev Anti Infect Ther. 2007; 5(5):893-901.

19. Tanyuksel M, Petri WA: Laboratory diagnosis of amebiasis. Clin. Microbiol. Rev. 2003; 16(4):713-729.

20. Samie A, El Bakri A, Odeh RA: Amoebiasis in the tropics: epidemiology and pathogenesis. [Internet]. [dounload 2019 Agt 27]. Available on: http://cdn.intechopen.com/pdfs/32498/InTech-

Amoebiasis_in_the_tropics_epidemiology_and_pathogen esis.pdf. 2012.

21. Clark CG, Stensvold RC: The Continuously Expanding Universe of Entamoeba. Available on: Nozaki T, Bhattacharyaeditor A editor, Amebiasis Biology and Pathogenesis of Entamoeba. Springer. Tokyo (JP). p: 925. 2014.

22. Parija SC, Mandal J, Ponnambath DK: Laboratory methods of identification of Entamoeba histolytica and its differentiation from look-alike Entamoeba spp. Trop Parasitol. 2014; 4(2):90-95.

23. Fotedar R, Stark D, Beebe D, et al. : Laboratory diagnostic techniques for entamoeba species. Clinical Microbiology Reviews. 2007; 20(3):511-532.

24. Gilchrist CA, Petri SE, Schneider BN, et al. : Role of the gut microbiota of children in diarrhea due to the protozoan parasite entamoeba histolytica, 2016; 213 : 1579-1585.

25. Arredondo JLM, González MPB, Coria AL, et al. : Ortega Entamoeba histolytica: trophozoite, precyst, and cyst studied by atomic force microscopy. Formatex 153-160. [Internet]. [dounload 2019 Agt 2]. Available on: http://www.formatex.info/microscopy6/book/153160.pdf. 2014.

26. Hamzah Z, Petmitr S, Mungthin M, et al. : Differential detection of Entamoeba histolytica, Entamoeba dispar, and Entamoeba moshkovskii by a single-round PCR assay. J Clin Microbiol. 2006; 44(9):3196-3200. 
27. Ehrenkaufer GM, Haque R, Hackney JA, et al. : Identification of developmentally regulated genes in Entamoeba histolytica: insights into mechanisms of stage conversion in a protozoan parasite. Cellular Microbiology. 2007; 9(6):1426-1444.

28. Rozaliyani A, Setyastutir H, Nawaso MA, et al. : Diagnosis dan penatalaksanaan empiema amuba. Maj Kedokt Indon. 2010; 60(11): 526-539

29. Ridley JW: Parasitology for Medical and Clinical Laboratory Professionals. Dickinson S, Bellegarde M. Delmar, Cengage Learning. (US) New York. 2012.

30. Stark D, Hal SJ, Matthews G, et al. : . Invasive amebiasis in men who have sex with men, Australia. Emerg Infect Dis. 2008; 14(7):1141-1143.

31. Erdog rul O”, Sener H: The contamination of various fruit and vegetable with Enterobius vermicularis, Ascaris eggs, Entamoeba histolyca cysts and Giardia cysts. Food Control. 2005; 16:559-562 Elsevier Ltd.

32. Barro'n-Gonza'lez MP, Villarreal-Treviño L, Rese'ndezPe'rez D, et al. : Entamoeba histolytica: Cyst-like structures in vitro induction. Experimental Parasitology. 2008; 118:600-603

33. Subahar R, Sutanto L: Ascaris lumbricoides eggs and human-intestinal protozoan cysts found in river water of Angke river, Jakarta. Makara Kesehatan. 2008; 12(2):83-85.

34. Yoshida N, Kevin M, Tyler KM, et al. : Invasion mechanisms among emerging food-borne protozoan parasites [ulasan]. Trends in Parasitology. 2011; 27(10):459-466.

35. Hubálek Z: Emerging human infectious diseases: anthroponoses, zoonoses, and sapronoses. Emerging infectious diseases. 2003; 9(3): 403-404.

36. WHO (World Health Organization): Pedoman Tekiik Dasar untuk Laboratorium Kesehatan. Editor, Mahode AA. Penerjemah, Chairlan dan Lestari. Jakarta. (ID): EGC. 2011.

37. Kline K, McCarthy JS, Pearson M, et al. : Neglected Tropical Diseases of Oceania: Review of Their Prevalence, Distribution, and Opportunities for Control. PLOS Neglected Tropical Diseases. 2013; 7(1):1-9
38. Wittnich C: Case report Entamoeba histolytica infection in a german shepherd dog. Can. Vet. Jour. 1976; 17(10): 259-263.

39. Shimada A, Muraki Y, Awakura T, et al. : Necrotic Colitis Associated with Entamoeba histolytica Infection in a Cat. J. Iump. Path. 1992; 106: 195-199.

40. European Association of Zoo and Wildlife Veterinarians: Amoebiasis. 4th edition. Brussels (BE): IDWG. 2010.

41. Regan CS, Yon L, Hossain M, et al. : Prevalence of Entamoeba species in captive primates in zoological gardens in the UK. PeerJ. 2014; 1-16.

42. Thompson RCA, Smith A: Zoonotic enteric protozoa. Veterinary Parasitology. 2011; 182:70-78.

43. Anonamous. Entamoeba histolytica: [download 2019 Jul 27]. available in: https://en.wikipedia.org/wiki/Entamoeba_histolytica

44. Anorital, Andayasari L: Kajian epidemiologi penyakit infeksi saluran pencernaan yang disebabkan oleh amuba di Indonesia. Media Litbang Kesehatan. 2011; 21(1):1-9.

45. Ben Ayed L, Sabbahi S: Entamoeba histolytica. In: J.B. Rose and B. Jiménez-Cisneros, (eds) Global Water Pathogen Project. http://www.waterpathogens.org (R. Fayer and W. Jakubowski, (eds) Part 3 Protists) www.waterpathogens.org/book/entamoeba-histolytica Michigan State University, E. Lansing, MI, UNESCO. 2017.

46. Pham Duc P, Nguyen-Viet H, Hattendorf J, et al. : Risk factors for Entamoeba histolytica infection in an agricultural community in Hanam province, Vietnam. Parasit Vectors. 2011; 4:102.

47. Robertson LJ: Parasitic protozoa in salad vegetables. Di dalam: P. Kotzekidou P, editor. Food Hygiene and Toxicology in Ready-to-Eat Foods. Elsevier Inc. 2016.

48. Deloer S, Nakamura R, Mi-Ichi F, et al. : Mouse models of amoebiasis and culture methods of amoeba. Parasitol Int. 2016; 65(5 Pt B):520-525. 